\title{
Potential Anticancer Mechanisms of a Novel EGFR/DNA-Targeting Combi-Molecule (JDF12) against DU145 Prostate Cancer Cells: An iTRAQ-Based Proteomic Analysis
}

\author{
Haofeng Zheng, ${ }^{1}$ Guancan Liang, ${ }^{1}$ Yanxiong Chen, ${ }^{1}$ Sijie Lin, ${ }^{1}$ \\ Wei Liu, ${ }^{2}$ and Youqiang Fang ${ }^{1}$ \\ ${ }^{1}$ Department of Urology, The Third Affiliated Hospital of Sun Yat-Sen University, Guangzhou 510630, China \\ ${ }^{2}$ Guangdong Provincial Key Laboratory of Liver Disease Research, The Third Affiliated Hospital of Sun Yat-Sen University, \\ Guangzhou 510630, China \\ Correspondence should be addressed to Youqiang Fang; fangyq@mail.sysu.edu.cn
}

Received 30 May 2017; Revised 22 August 2017; Accepted 10 September 2017; Published 15 October 2017

Academic Editor: Paul W. Doetsch

Copyright (c) 2017 Haofeng Zheng et al. This is an open access article distributed under the Creative Commons Attribution License, which permits unrestricted use, distribution, and reproduction in any medium, provided the original work is properly cited.

\begin{abstract}
The development of multitargeting drugs is an emerging trend in cancer research. To promote further development and clinical application of multitargeting drugs, this research was performed. MTT assay and flow cytometry of Annexin V/propidium iodide staining were used to confirm the proapoptotic efficacy of a novel combi-targeting molecule, JDF12, against DU145 prostate cancer (PCa) cells. Differentially expressed proteins between control and JDF12-treated cultures were revealed by isobaric tags for relative and absolute quantitation (iTRAQ), and part of them was confirmed by quantitative PCR. Differentially expressed proteins were further analyzed for function, pathway association, and protein-protein interactions using GO, KEGG, and STRING databases. A total of 119 differentially expressed proteins, 70 upregulated and 49 downregulated, were implicated in the anticancer effects of JDF12. Many of these proteins are involved in biosynthesis, response to stress, energy metabolism, and signal transduction. This study provides important information for understanding the anti-PCa mechanisms of JDF12, and well-designed combitargeting drugs may possess stronger anticancer efficacy than single-targeting drugs and are thus promising candidates for clinical application.
\end{abstract}

\section{Introduction}

Prostate cancer $(\mathrm{PCa})$ is one of the most commonly diagnosed solid organ malignancies and remains the third leading cause of cancer death among men in the United States [1]. It is estimated that more than 161,000 new PCa diagnoses and over 26,000 deaths will occur in America during 2017 [2]. Metastatic castration-resistant prostate cancer (mCRPC) is the end stage of $\mathrm{PCa}$, and often leads to death within two years [3].

While many therapies are initially effective, recurrence and treatment failure are common. Acquired drug resistance and other changes in the biological behavior of cancer cells are major impediments to long-term control or cure $[4,5]$. Joint use of multiplex drugs may lessen drug resistance, but serious drugs toxicities have been reported [6]. In light of these problems, development of multitargeting drugs is one promising alternative [7]. In our previous studies, we developed a combi-targeting molecule, JDF12, with both antiepidermal growth factor receptor (EGFR) and DNAalkylating properties. In situ, JDF12 is hydrolyzed to JDF04R, which can inhibit the phosphorylation of EGFR and activation of isolated EGFR tyrosine kinase. In addition, JDF12 is hydrolyzed to a DNA-alkylating agent [8]. Subsequent studies showed that JDF12 exhibited not only stronger anticancer effects than single drugs or joint use of two drugs at equivalent doses, but also better toxicity profiles and lower drug resistance rate $[9,10]$.

Although the anticancer effects of JDF12 are well described, the detailed molecular mechanisms of its anticancer efficacy are incompletely understood, preventing further clinical applications. The current study was designed 
to identify the potential anticancer mechanisms of JDF12 and assess the potential of this combi-targeting drug for anticancer therapy.

\section{Materials and Methods}

2.1. Drug Treatment. The combi-targeting drug JDF12 was synthesized as described in our previous study [9]. The drug was kept at $-20^{\circ} \mathrm{C}$ and dissolved in dimethyl sulfoxide (DMSO) for in vitro application. Fetal bovine serum (FBS, $10 \%$ ) was used as a diluent so that the final DMSO concentration was below $0.2 \%$.

2.2. Cell Culture. The human PCa cell line DU145, PC3, and 22Rvl were obtained from the cell bank of the Type Culture Collection of the Chinese Academy of Sciences (Shanghai, China). Cells were cultured in RPMI-1640 medium (Gibco, USA) supplemented with 10\% FBS (PAN, Germany) and maintained at $37^{\circ} \mathrm{C}$ in a humidified incubator under a $5 \%$ $\mathrm{CO}_{2} / 95 \%$ air atmosphere. Cells were subcultured every $2-3$ days as previously described [9].

2.3. Cell Viability. Cells in log-phase were plated at $5 \times$ $10^{3} /$ well in 96 -well plates for $24 \mathrm{~h}$. Cells were then treated with a range of JDF12 concentrations for $48 \mathrm{~h}$. An MTT kit (KeyGEN BioTECH, Jiangsu, China) was used to determine cell viability according to the manufacturer's protocol. Briefly, MTT was added to each well $(0.5 \mathrm{mg} / \mathrm{ml}$ final concentration) for $4 \mathrm{~h}$ following JDF12 treatment. The crystals produced from MTT by viable cells were dissolved in $150 \mu \mathrm{l}$ DMSO for $15 \mathrm{~min}$ and optical density was measured on a microplate reader (BioRab, USA) at $490 \mathrm{~nm}$. The halfmaximal inhibitory concentration $\left(\mathrm{IC}_{50}\right)$ of JDF12 was determined from the dose-response curve. In addition, the time course of survival at the $\mathrm{IC}_{50}$ was measured over $48 \mathrm{~h}$. Three independent experiments were performed at each concentration.

2.4. Flow Cytometry. An Apoptosis Detection Kit (KeyGEN) for Annexin V-FITC and propidium iodide (PI) staining was used to assess cell apoptosis. Briefly, cells treated as described were washed with ice-cold PBS, harvested by trypsinization, and resuspended in binding buffer at $1 \times 10^{6}$ cells $/ \mathrm{mL}$. Then, $500 \mu \mathrm{L}$ cell suspension (approximately $5 \times 10^{5}$ cells) was incubated with $5 \mu \mathrm{L}$ PI $(0.5 \mathrm{mg} / \mathrm{mL})$ and $5 \mu \mathrm{L}$ Annexin V-FITC for $15 \mathrm{~min}$ at $25^{\circ} \mathrm{C}$ in the dark. A flow cytometer (FACSCalibur, Becton Dickinson, San Jose, CA, USA) with emission at $530 \mathrm{~nm}$ for FITC and $630 \mathrm{~nm}$ for PI and excitation at $488 \mathrm{~nm}$ was used to analyze the proportions of cells in early and late apoptosis. Three independent experiments were performed at each time point.

\section{5. iTRAQ Proteome Analysis}

2.5.1. Protein Extraction. DU145 cells were seeded in $75-\mathrm{cm}^{2}$ flasks $\left(1 \times 10^{6}\right.$ cells) for $24 \mathrm{~h}$ and treated with the JDF12 $\mathrm{IC}_{50}$ concentration for an additional $24 \mathrm{~h}$. Cells were then washed thoroughly with ice-cold PBS and lysed with RIPA buffer (KeyGEN) according to the manufacturer's instructions.
Lysates were centrifuged at $12000 \times \mathrm{g}$ for $20 \mathrm{~min}$ at $4^{\circ} \mathrm{C}$ and the protein concentration of each supernatant sample was measured using a BCA protein assay kit (KeyGEN). The extracted protein solutions were stored at $-80^{\circ} \mathrm{C}$ for later analysis with no repeat freeze-thaw cycles.

2.5.2. Trypsin Digestion and iTRAQ Labeling. The reagents and buffers for isobaric tags for relative and absolute quantitation (iTRAQ) labeling and cleaning were purchased from Applied Biosystems (Foster City, CA, USA). The iTRAQ labeling assay was conducted according to the manufacturer instructions. Briefly, $100 \mu \mathrm{g}$ of each protein sample was dissolved, alkylated, and digested with trypsin (Promega, Madison, WI, USA). After vacuum freeze-drying, the digested peptides were reconstituted in $50 \mu \mathrm{L}$ of $0.5 \mathrm{M}$ triethylammonium bicarbonate. Peptides were then processed with an iTRAQ-8plex kit. Each sample was labeled with two tags (blank group: 113, 117; JDF12 group: 115, 119). Finally, all labeled samples were mixed in a single vial and dried using a rotary vacuum concentrator.

2.5.3. High $\mathrm{pH}$ Reversed-Phase Fractionation. High $\mathrm{pH}$ reversed-phase fractionation was performed using a highperformance liquid chromatography system (Phenomenex columns; Gemini-NX 3u C18 110A; $150 \times 2.00$ mm). Separation of the labeled peptides was achieved by a linear gradient of mobile phase A $\left(20 \mathrm{mM} \mathrm{HCOONH}_{4}, \mathrm{pH}=10\right)$ to mobile phase $\mathrm{B}\left(20 \mathrm{mM} \mathrm{HCOONH}_{4}, 80 \%\right.$ acetonitrile $(\mathrm{ACN}), \mathrm{pH}=$ 10). The UV detection wavelengths were $214 \mathrm{~nm} / 280 \mathrm{~nm}$. Depending on the peak and time, fractions were collected every $1 \mathrm{~min}$, for a total of 24 fractions. The fractions were acidified with $50 \%$ trifluoroacetic acid and dried by vacuum centrifuge.

2.5.4. Reverse-Phase LC-MS Analysis. Peptide samples were dissolved in buffer $(0.1 \%$ formic acid, $2 \%$ acetonitrile) and centrifuged at $12,000 \times \mathrm{g}$ for $20 \mathrm{~min}$ at $4^{\circ} \mathrm{C}$. The peptides were eluted with a linear gradient of buffer $\mathrm{A}$ ( $0.1 \%$ formic acid) to buffer B $(0.1 \%$ formic acid, $80 \% \mathrm{ACN})$ at a flow rate of $330 \mathrm{~nL} / \mathrm{min}$ for a total of $60 \mathrm{~min}$. The Q Exactive system was used for MS/MS analysis in information-dependent acquisition mode. Mass spectra were acquired over a scan range of 350 to $1800 \mathrm{~m} / z$ with a resolution of 70,000 using maximum injection time $(40 \mathrm{~ms})$ per spectrum. Fragmentation detection used the twenty most intense precursors per MS cycle with $60 \mathrm{~ms}$ maximum injection time. Tandem mass spectra were recorded at a resolution of 17,500 with iTRAQ reagent collision energy adjustment "ON" and rolling collision energy "ON."

2.5.5. Protein Identification and Quantification. Protein identification and quantification results were analyzed by ProteinPilot $^{\mathrm{TM}}$ Software 5.0 (AB SCIEX) using the Paragon ${ }^{\mathrm{TM}}$ Algorithm (5.0.0.0, 4767). Each MS/MS spectrum was searched against the Uniprot/Swiss-Prot Database for Homo sapiens. Parameters for searching were as follows: (1) Detected Protein Threshold: 0.05; (2) Competitor Error Margin: 2.00; (3) Revision Number: 4769; (4) Instrument: Orbi MS (1-3 ppm), Orbi MS/MS; (5) Sample Type: iTRAQ 8 plex (Peptide 


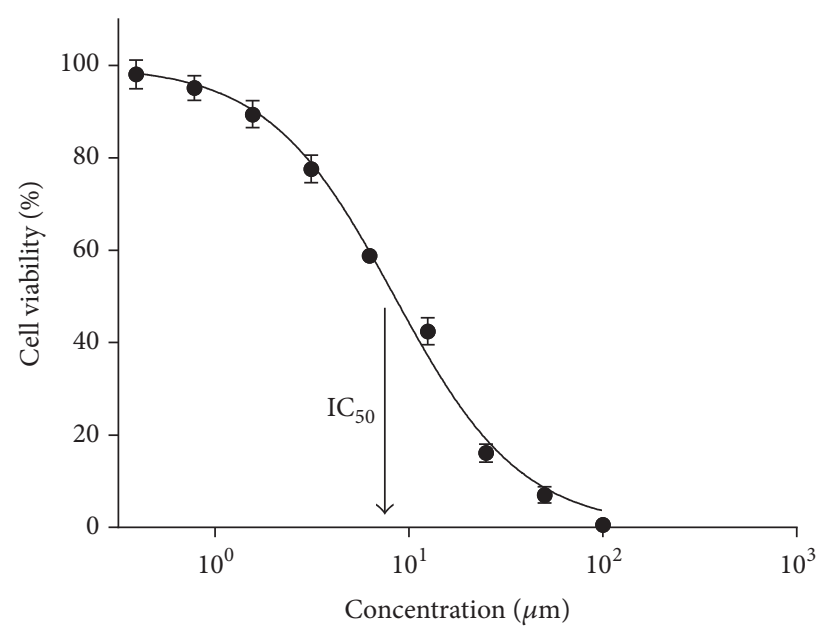

(a)

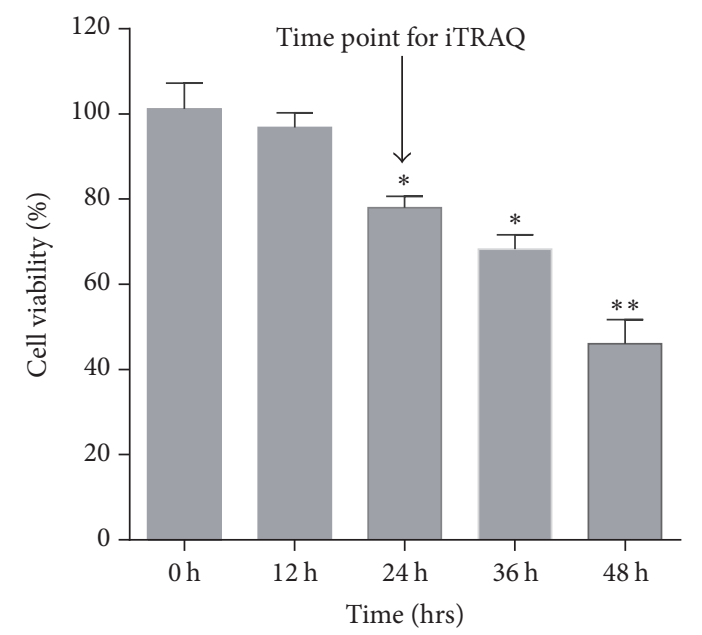

(b)

FIGURE 1: The effects of JDF12 on the cell viability. (a) Concentration course of changes in the cell viability of DU145 cells treated with JDF12 for $48 \mathrm{~h}$; (b) Time course of changes in the cell viability of DU145 cells treated with IC $_{50}$ JDF12. Data was expressed as mean \pm SD of 5 determinations from three independent experiments and compared to the blank group $(0 \mathrm{~h}),{ }^{*} p<0.05$ and ${ }^{* *} p<0.01$.

Labeled); (6) Cysteine Alkylation: MMTS; (7) Digestion: Trypsin; (8) Special Factors: none; (9) ID Focus: biological modifications; (10) Search Effort: thorough ID; (11) FDR Analysis: yes; (12) User Modified Parameter Files: no. Qualification criteria for peptides were unused confidence score $\geq 1.3$ and confidence level $\geq 95 \%$. Proteins containing at least one peptide and false discovery rate (FDR) $<1 \%$ were accepted. Proteins with poor repeatability (coefficient of variation $>0.5$ ) or no quantitative information were removed. For qualifying proteins, average fold change $\geq 1.5$ was classified as upregulated and average fold change $\leq 0.67$ was defined as downregulated.

2.6. Gene Ontology and KEGG Pathway Enrichment Analysis. The biological functions of the significantly up- or downregulated proteins were analyzed using web-based Gene Ontology (GO) software (http://www.geneontology.org/). There are three main modules in the GO project: biological process, cellular component, and molecular function. Pathway analysis was conducted using by the web-based Kyoto Encyclopedia of Genes and Genomes (KEGG, http://www.kegg.jp/). Hierarchical clustering is presented with java Tree view using Cluster 3.0. Known and predicted protein-protein interaction networks of differentially expressed proteins were built based on the publicly available Search Tool for the Retrieval of Interacting Genes/Proteins (STRING) database (http://string-db.org/). FDR adjusted $p$ value of 0.05 was considered statistically significant.

2.7. qPCR Analysis. Total RNA was extracted using the TRIzol Reagent (Life Technologies ${ }^{\mathrm{TM}}$ ) according to the manufacturer's protocol. cDNA was synthesized from $1 \mu \mathrm{g}$ of total RNA using the Transcript of First Strand cDNA Synthesis Kit (Roche). Quantitative (q)PCR was performed on a Light Cycler 480 (Roche) using SYBR Green PCR Master Mix according to the manufacturer's instructions. $\beta$-Actin was used as the endogenous control to normalize target gene expression. Primers were synthesized by Ruibotech (Beijing, China). Relative RNA expression was calculated by the $2^{-\Delta \Delta C T}$ method. All samples were measured three times, and results are shown as mean \pm standard deviation.

2.8. Statistical Analysis. Group means were compared by independent samples $t$-test, with $p<0.05$ considered statistically significant. SPSS version 19.0 (Chicago, Illinois, USA) was used for all statistical calculations.

\section{Results}

3.1. JDF12 Reduces Viable Prostate Cancer Cell Number. Human PCa-derived DU145 cells treated with JDF12 from 0.39 to $100.00 \mu \mathrm{M}$ for $48 \mathrm{~h}$ exhibited a progressive decrease in viable cell number as measured by MTT assay, and doseresponse curves yielded an average $( \pm \mathrm{SD}) \mathrm{IC}_{50}$ value of $8.42 \pm 0.40 \mu \mathrm{M}$ (Figure 1(a)). During application of the $\mathrm{IC}_{50}$ dose, no significant reduction in cell number was observed at $12 \mathrm{~h}$, while significant reductions were observed at $24 \mathrm{~h}$ or longer (Figure 1(b)). A 24-h treatment time was selected for subsequent apoptosis and proteomics measures. MTT results of $22 \mathrm{Rv} 1$ and PC3 cell lines at $48 \mathrm{~h}$ are shown in Supplemental Figure 1 in Supplementary Material, available online at https://doi.org/10.1155/2017/8050313.

3.2. Induction of PCa Cell Apoptosis by JDF12. Figure 2 shows the apoptosis rates in the blank control and JDF12-treated groups as measured by flow cytometry of Annexin V/PIstained cells (Annexin V+/PI- indicates early apoptosis and $\mathrm{V}+/ \mathrm{PI}+$ indicates late apoptosis). Early and late apoptosis rates were summed to yield an overall apoptosis rate for this study. Cell apoptosis rate was significantly increased by 24 and $48 \mathrm{~h}$ treatment with JDF12 at the $\mathrm{IC}_{50}(8.42 \mu \mathrm{M})$ compared to the blank group $(0 \mathrm{~h})$. 
TABLE 1: Differentially expressed proteins detected by iTRAQ after being treated with JDF12 in DU145 cells.

\begin{tabular}{|c|c|c|c|c|}
\hline Number & $\begin{array}{c}\text { Accession } \\
\text { number }\end{array}$ & $\begin{array}{l}\text { Gene } \\
\text { name }\end{array}$ & Protein name & Fold change \\
\hline \multicolumn{5}{|c|}{ Upregulated proteins } \\
\hline (1) & Q5T2R2 & PDSS1 & Decaprenyl-diphosphate synthase subunit 1 & 34.52 \\
\hline (2) & Q96HN1 & PLEKHG4B & PLEKHG4B protein (Fragment) & 10.23 \\
\hline (3) & Q14914 & PTGR1 & Prostaglandin reductase 1 & 3.78 \\
\hline (4) & P09914 & IFIT1 & Interferon-induced protein with tetratricopeptide repeats 1 & 3.46 \\
\hline (5) & A0A0C4DGB6 & ALB & Serum albumin & 2.47 \\
\hline (6) & C9JIZ6 & PSAP & Prosaposin & 2.42 \\
\hline$(7)$ & Q53EL6 & PDCD4 & Programmed cell death protein 4 & 2.41 \\
\hline (8) & F8W8T1 & MX1 & Interferon-induced GTP-binding protein $\mathrm{Mxl}$ & 2.30 \\
\hline (9) & P09382 & LGALS1 & Galectin-1 & 2.27 \\
\hline (10) & H0YIV4 & NAP1L1 & Nucleosome assembly protein 1-like 1 & 2.17 \\
\hline (11) & P18669 & PGAM1 & Phosphoglycerate mutase 1 & 2.14 \\
\hline (12) & P12883 & MYH7 & Myosin-7 & 2.11 \\
\hline (13) & P16615 & ATP2A2 & Sarcoplasmic/endoplasmic reticulum calcium ATPase 2 & 2.05 \\
\hline (14) & P49006 & MARCKSL1 & MARCKS-related protein & 2.02 \\
\hline$(15)$ & Q6PJG6 & BRAT1 & BRCA1-associated ATM activator 1 & 1.97 \\
\hline (16) & Q9Y5A7 & NUB1 & NEDD8 ultimate buster 1 & 1.96 \\
\hline (17) & Q03169 & TNFAIP2 & Tumor necrosis factor alpha-induced protein 2 & 1.92 \\
\hline (18) & Q99536 & VAT1 & Synaptic vesicle membrane protein VAT-1 homolog & 1.92 \\
\hline (19) & P38919 & EIF4A3 & Eukaryotic initiation factor $4 \mathrm{~A}-\mathrm{III}$ & 1.91 \\
\hline$(20)$ & Q96AQ6 & PBXIP1 & Pre-B-cell leukemia transcription factor-interacting protein 1 & 1.89 \\
\hline (21) & Q9UIJ7 & AK3 & GTP: AMP phosphotransferase AK3, mitochondrial & 1.84 \\
\hline$(22)$ & P04080 & CSTB & Cystatin-B & 1.83 \\
\hline$(23)$ & P12277 & $\mathrm{CKB}$ & Creatine kinase B-type & 1.83 \\
\hline$(24)$ & P62937 & PPIA & Peptidyl-prolyl cis-trans isomerase A & 1.82 \\
\hline$(25)$ & P52630 & STAT2 & Signal transducer and activator of transcription 2 & 1.81 \\
\hline (26) & P14625 & HSP90B1 & Endoplasmin & 1.80 \\
\hline$(27)$ & Q6PJG6 & BART1 & BRCA1-associated ATM activator 1 & 1.79 \\
\hline$(28)$ & Q9BTT0 & ANP32E & Acidic leucine-rich nuclear phosphoprotein 32 family member $\mathrm{E}$ & 1.79 \\
\hline$(29)$ & Q01581 & HMGCS1 & Hydroxymethylglutaryl-CoA synthase, cytoplasmic & 1.79 \\
\hline$(30)$ & Q5T9B7 & AK1 & Adenylate kinase isoenzyme 1 & 1.78 \\
\hline$(31)$ & J3KQL8 & APOL2 & Apolipoprotein L2 & 1.76 \\
\hline (32) & P62750 & RPL23A & 60 S ribosomal protein L23a & 1.75 \\
\hline (33) & Q14980 & NUMA1 & Nuclear mitotic apparatus protein 1 & 1.73 \\
\hline$(34)$ & P28066 & PSMA5 & Proteasome subunit alpha type- 5 & 1.72 \\
\hline$(35)$ & P23528 & CFL1 & Cofilin-1 & 1.71 \\
\hline$(36)$ & Q8IY63 & AMOTL1 & Angiomotin-like protein 1 & 1.71 \\
\hline$(37)$ & Q8TBX8 & PIP4K2C & Phosphatidylinositol 5-phosphate 4-kinase type-2 gamma & 1.70 \\
\hline$(38)$ & P28799 & GRN & Granulins & 1.68 \\
\hline$(39)$ & P04792 & HSPB1 & Heat shock protein beta-1 & 1.67 \\
\hline$(40)$ & P11021 & HSPA5 & $78 \mathrm{kDa}$ glucose-regulated protein & 1.67 \\
\hline (41) & A0A0A0MSZ4 & FDXR & NADPH: adrenodoxin oxidoreductase, mitochondrial & 1.65 \\
\hline$(42)$ & O94992 & HEXIM1 & Protein HEXIM1 & 1.65 \\
\hline (43) & P31949 & S100A11 & Protein S100-A11 & 1.64 \\
\hline$(44)$ & Q04828 & AKR1C1 & Aldo-keto reductase family 1 member $\mathrm{Cl}$ & 1.63 \\
\hline$(45)$ & Q13263 & TRIM28 & Transcription intermediary factor 1-beta & 1.63 \\
\hline
\end{tabular}


TABle 1: Continued.

\begin{tabular}{|c|c|c|c|c|}
\hline Number & $\begin{array}{c}\text { Accession } \\
\text { number }\end{array}$ & $\begin{array}{l}\text { Gene } \\
\text { name }\end{array}$ & Protein name & Fold change \\
\hline$(46)$ & Q8IVF2 & AHNAK2 & Protein AHNAK2 & 1.63 \\
\hline$(47)$ & Q9NVP2 & ASF1B & Histone chaperone ASF1B & 1.63 \\
\hline$(48)$ & O75874 & IDH1 & Isocitrate dehydrogenase [NADP] cytoplasmic & 1.62 \\
\hline (49) & O96008 & TOMM40 & Mitochondrial import receptor subunit TOM40 homolog & 1.61 \\
\hline$(50)$ & P27449 & ATP6V0C & V-type proton ATPase $16 \mathrm{kDa}$ proteolipid subunit & 1.61 \\
\hline$(51)$ & P06733 & ENO1 & Alpha-enolase & 1.60 \\
\hline$(52)$ & Q00688 & FKBP3 & Peptidyl-prolyl cis-trans isomerase FKBP3 & 1.60 \\
\hline (53) & A0A0U1RQC9 & TP53 & Cellular tumor antigen $\mathrm{p} 53$ & 1.59 \\
\hline$(54)$ & Q9Y6K5 & OAS3 & $2^{\prime}-5^{\prime}$-Oligoadenylate synthase 3 & 1.59 \\
\hline$(55)$ & P46977 & STT3A & $\begin{array}{c}\text { Dolichyl-diphosphooligosaccharide-protein glycosyltransferase } \\
\text { subunit STT3A }\end{array}$ & 1.58 \\
\hline$(56)$ & Q9UNS1 & TIMELESS & Protein timeless homolog & 1.58 \\
\hline$(57)$ & E9PFR3 & PPP2R5D & $\begin{array}{c}\text { Serine/threonine-protein phosphatase } 2 \mathrm{~A} 56 \mathrm{kDa} \text { regulatory subunit } \\
\text { delta isoform }\end{array}$ & 1.57 \\
\hline$(58)$ & Q14764 & MVP & Major vault protein & 1.57 \\
\hline (59) & O75083 & WDR1 & WD repeat-containing protein 1 & 1.56 \\
\hline$(60)$ & P04075 & ALDOA & Fructose-bisphosphate aldolase A & 1.56 \\
\hline$(61)$ & P09601 & HMOX1 & Heme oxygenase 1 & 1.56 \\
\hline$(62)$ & Q16678 & CYP1B1 & Cytochrome P450 1B1 & 1.56 \\
\hline (63) & P62158 & CALM1 & Calmodulin & 1.55 \\
\hline (64) & Q06830 & PRDX1 & Peroxiredoxin-1 & 1.55 \\
\hline (65) & P13667 & PDIA4 & Protein disulfide-isomerase A4 & 1.54 \\
\hline$(66)$ & P22223 & $\mathrm{CDH} 3$ & Cadherin-3 & 1.54 \\
\hline$(67)$ & P15121 & AKR1B1 & Aldose reductase & 1.53 \\
\hline$(68)$ & P30050 & RPL12 & $60 S$ ribosomal protein L12 & 1.53 \\
\hline (69) & Q9BXP5 & SRRT & Serrate RNA effector molecule homolog & 1.52 \\
\hline$(70)$ & H0Y4G9 & MYD88 & Myeloid differentiation primary response protein MyD88 & 1.50 \\
\hline \multicolumn{5}{|c|}{ Downregulated proteins } \\
\hline$(71)$ & P13645 & KRT10 & Keratin, type I cytoskeletal 10 & 0.27 \\
\hline$(72)$ & O95155 & UBE4B & Ubiquitin conjugation factor $\mathrm{E} 4 \mathrm{~B}$ & 0.38 \\
\hline (73) & Q9BYX7 & POTEKP & Putative beta-actin-like protein 3 & 0.39 \\
\hline$(74)$ & P26599 & PTBP1 & Polypyrimidine tract-binding protein 1 & 0.44 \\
\hline$(75)$ & P52789 & HK2 & Hexokinase- 2 & 0.44 \\
\hline$(76)$ & Q53EP0 & FNDC3B & Fibronectin type III domain-containing protein 3B & 0.44 \\
\hline$(77)$ & P35908 & KRT2 & Keratin, type II cytoskeletal 2 epidermal & 0.45 \\
\hline$(78)$ & P04264 & KRT1 & Keratin, type II cytoskeletal 1 & 0.45 \\
\hline (79) & $\mathrm{O} 43854$ & EDIL3 & EGF-like repeat and discoidin I-like domain-containing protein 3 & 0.46 \\
\hline$(80)$ & F5H039 & GPHN & Gephyrin & 0.48 \\
\hline$(81)$ & F8W727 & RPL32 & $60 \mathrm{~S}$ ribosomal protein $\mathrm{L} 32$ & 0.50 \\
\hline$(82)$ & O43760 & SYNGR2 & Synaptogyrin-2 & 0.50 \\
\hline$(83)$ & P05067 & APP & Amyloid beta A4 protein & 0.50 \\
\hline$(84)$ & Q14669 & TRIP12 & E3 ubiquitin-protein ligase TRIP12 & 0.51 \\
\hline$(85)$ & P29317 & EPHA2 & Ephrin type-A receptor 2 & 0.51 \\
\hline$(86)$ & F5H8D7 & XRCC1 & DNA repair protein XRCC1 & 0.51 \\
\hline$(87)$ & Q9Y4B5 & MTCL1 & Microtubule cross-linking factor 1 & 0.53 \\
\hline$(88)$ & Q13206 & DDX10 & Probable ATP-dependent RNA helicase DDX10 & 0.54 \\
\hline$(89)$ & P61513 & RPL37A & $60 S$ ribosomal protein $\mathrm{L} 37 \mathrm{a}$ & 0.55 \\
\hline$(90)$ & Q9NW82 & WDR70 & WD repeat-containing protein 70 & 0.56 \\
\hline
\end{tabular}


TABle 1: Continued.

\begin{tabular}{|c|c|c|c|c|}
\hline Number & $\begin{array}{c}\text { Accession } \\
\text { number }\end{array}$ & $\begin{array}{l}\text { Gene } \\
\text { name }\end{array}$ & Protein name & Fold change \\
\hline (91) & P00533 & EGFR & Epidermal growth factor receptor & 0.56 \\
\hline$(92)$ & Q8N556 & AFAP1 & Actin filament-associated protein 1 & 0.56 \\
\hline (93) & J3KNF8 & CYB5B & Cytochrome b5 type B & 0.56 \\
\hline$(94)$ & O15040 & TECPR2 & Tectonin beta-propeller repeat-containing protein 2 & 0.56 \\
\hline (95) & O94925 & GLS & Glutaminase kidney isoform, mitochondria & 0.57 \\
\hline$(96)$ & Q8N726 & CDKN2A & Tumor suppressor ARF & 0.58 \\
\hline$(97)$ & Q99650 & OSMR & Oncostatin-M-specific receptor subunit beta & 0.58 \\
\hline$(98)$ & P07992 & ERCC1 & DNA excision repair protein ERCC-1 & 0.58 \\
\hline (99) & O15091 & KIAA0391 & Mitochondrial ribonuclease $\mathrm{P}$ protein 3 & 0.60 \\
\hline$(100)$ & Q9NPQ8 & RIC8A & Synembryn-A & 0.60 \\
\hline$(101)$ & Q9Y617 & PSAT1 & Phosphoserine aminotransferase & 0.60 \\
\hline$(102)$ & Q03001 & DST & Dystonin & 0.61 \\
\hline (103) & Q13751 & LAMB3 & Laminin subunit beta-3 & 0.61 \\
\hline$(104)$ & Q9UPQ0 & LIMCH1 & LIM and calponin homology domains-containing protein 1 & 0.61 \\
\hline$(105)$ & O00308 & WWP2 & NEDD4-like E3 ubiquitin-protein ligase WWP2 & 0.62 \\
\hline$(106)$ & P13639 & EEF2 & Elongation factor 2 & 0.63 \\
\hline$(107)$ & P42892 & ECE1 & Endothelin-converting enzyme 1 & 0.63 \\
\hline$(108)$ & Q14571 & ITPR2 & Inositol 1,4,5-trisphosphate receptor type 2 & 0.63 \\
\hline$(109)$ & E9PER6 & PDPK1 & 3-Phosphoinositide-dependent protein kinase 1 & 0.64 \\
\hline$(110)$ & Q92974 & ARHGEF2 & Rho guanine nucleotide exchange factor 2 & 0.65 \\
\hline (111) & P26006 & ITGA3 & Integrin alpha-3 & 0.66 \\
\hline (112) & Q06481 & APLP2 & Amyloid-like protein 2 & 0.66 \\
\hline (113) & Q15050 & RRS1 & Ribosome biogenesis regulatory protein homolog & 0.66 \\
\hline (114) & Q15397 & PUM3 & Pumilio homolog 3 & 0.66 \\
\hline (115) & Q99700 & ATXN2 & Ataxin-2 & 0.66 \\
\hline$(116)$ & Q16706 & MAN2A1 & Alpha-mannosidase 2 & 0.67 \\
\hline$(117)$ & Q96HC4 & PDLIM5 & PDZ and LIM domain protein 5 & 0.67 \\
\hline (118) & P49643 & PRIM2 & DNA primase large subunit & 0.67 \\
\hline (119) & Q86YD1 & PTOV1 & Prostate tumor-overexpressed gene 1 protein & 0.67 \\
\hline
\end{tabular}

3.3. Effects of JDF12 on Protein Expression Levels in PCa Cells. An iTRAQ-based quantitative proteomics approach was used to measure the effects of JDF12 on protein expression levels in DU145 cells. A total of 5610 proteins were detected in the global proteomic analysis with a CV $<50 \%$ among replicates. Each protein had at least one identified peptide with an unused score $\geq 1.3$, indicating $>95 \%$ confidence in correct sequence identification. A total of 119 differentially expressed proteins (fold change $\geq 1.5$ or $\leq 0.67$ ) were identified by iTRAQ. Among them, 70 were upregulated and 49 were downregulated. These differentially expressed proteins are summarized in Table 1.

3.4. Functional Classification of Differentially Expressed Proteins. A total of $133 \mathrm{GO}$ terms, including 38 molecular function terms, 66 biological process terms, and 29 cellular component terms, were retrieved. Differentially expressed proteins were further analyzed by KEGG, and 75 proteins were mapped into KEGG pathways. "Metabolic", "microRNA", and "carbon metabolism" were most affected by
JDF12, suggesting that changes in these pathways/processes mediate the anticancer efficacy (Figure 3 and Supplemental Figure 2).

3.5. Interaction Analysis of Differentially Expressed Proteins. To identify interactions among differentially expressed proteins, STRING analysis was performed. One hundred and sixteen protein nodes and 90 edges were identified. The epidermal growth factor receptor (EGFR), tumor protein p53 (TP53), and heat shock protein A member 5 (HSPA5) were the top three hubs, indicating highest connectivity and greatest capacity to regulate the interaction network (Figures 4 and 5).

3.6. Confirmation of Differential Expression by qPCR. Quantitative PCR was performed to confirm expression changes of proteins with highest connectivity, including EGFR, TP53, HSPA5, excision repair cross-complementation group 1 (ERCC1), and X-ray repair cross complementing 1 (XRCC1), in several prostate cell lines. The expression levels of all 


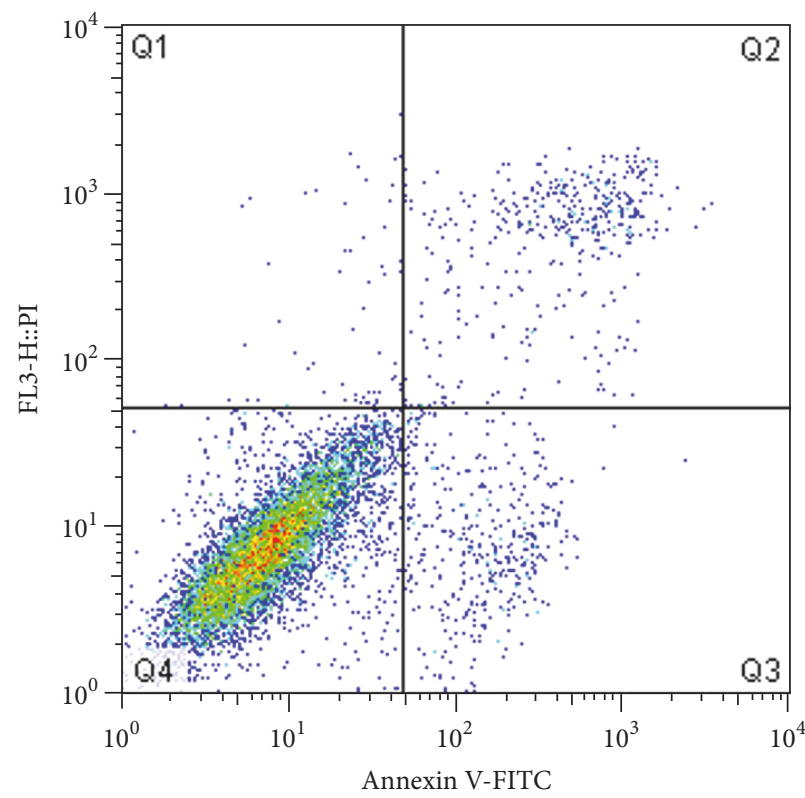

(a)

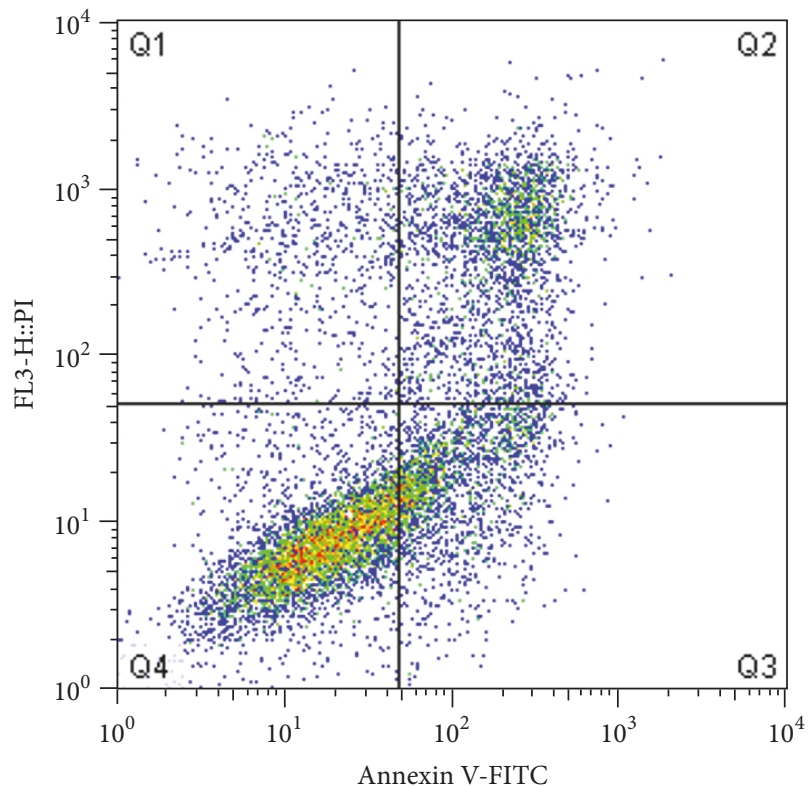

Annexin V-FITC

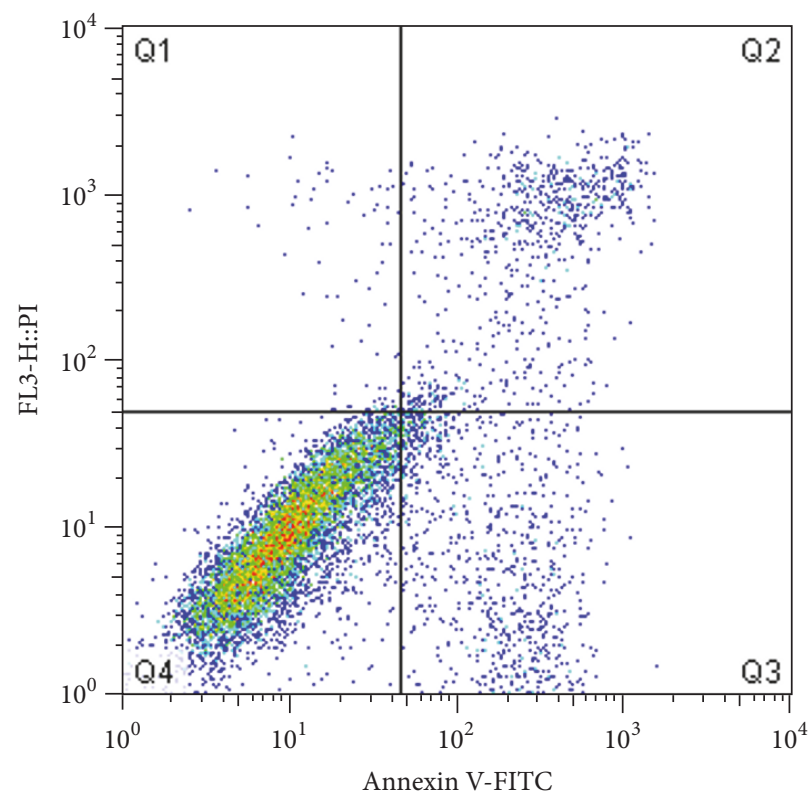

(b)

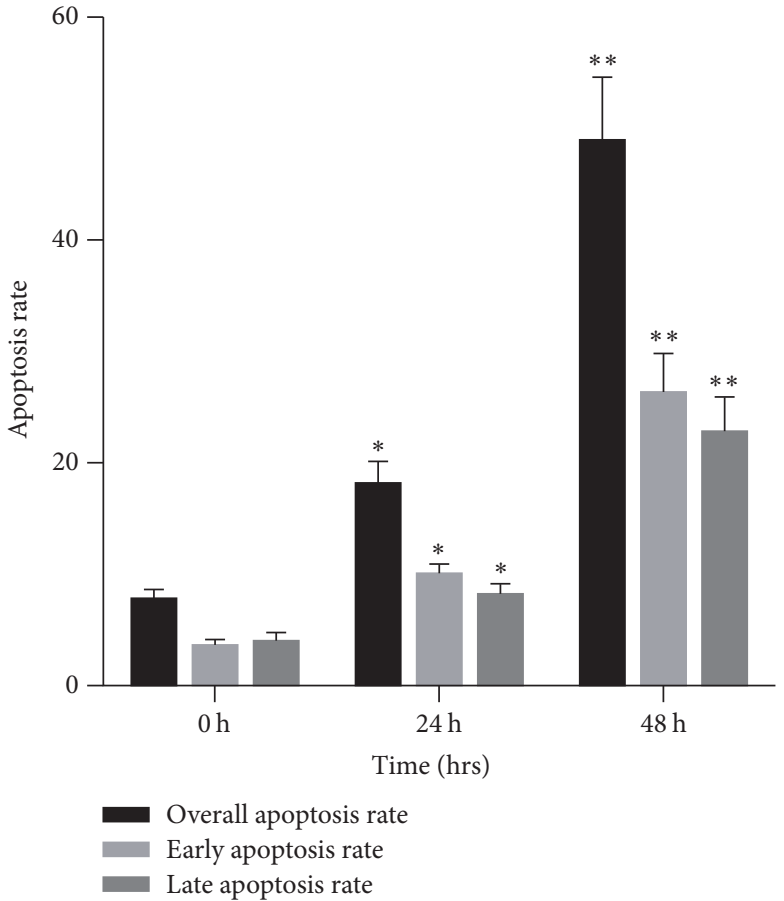

(d)

Figure 2: The effects of JDF12 on the cell apoptosis. Early apoptosis cells were Annexin V+/PI-, and later apoptosis cells were Annexin $\mathrm{V+} / \mathrm{PI}+$. (a) $0 \mathrm{~h}$; (b) $24 \mathrm{~h}$; (c) $48 \mathrm{~h}$; (d) the overall apoptosis rate was significant increased after treatment of $\mathrm{IC}_{50} \mathrm{JDF}^{2} \mathrm{for} 24 \mathrm{~h}$ and $48 \mathrm{~h}$. Results were presented as mean \pm SD from three independent experiments. ${ }^{*} p<0.05,{ }^{* *} p<0.01$.

these proteins in DU145 cells were significantly altered, including two upregulated and three downregulated, consistent with iTRAQ. The expressions of these five proteins in other prostate cell lines including PC3 and 22Rv1 were also confirmed by qPCR. All proteins excluding ERCC1 were significantly altered, consistent with results in DU145 cell line. As for ERCC1, no significant difference was found in PC3 and 22Rvl cell lines (Figure 6).

\section{Discussion}

This study identified potential molecular mechanisms underlying the anticancer efficacy of the combi-targeting molecule JDF12. Proteomics analysis revealed a myriad of differentially expressed proteins and several signaling pathways strongly linked to JDF12-induced apoptosis, including EGFR and TP53 pathways (Figure 7). These differentially expressed 


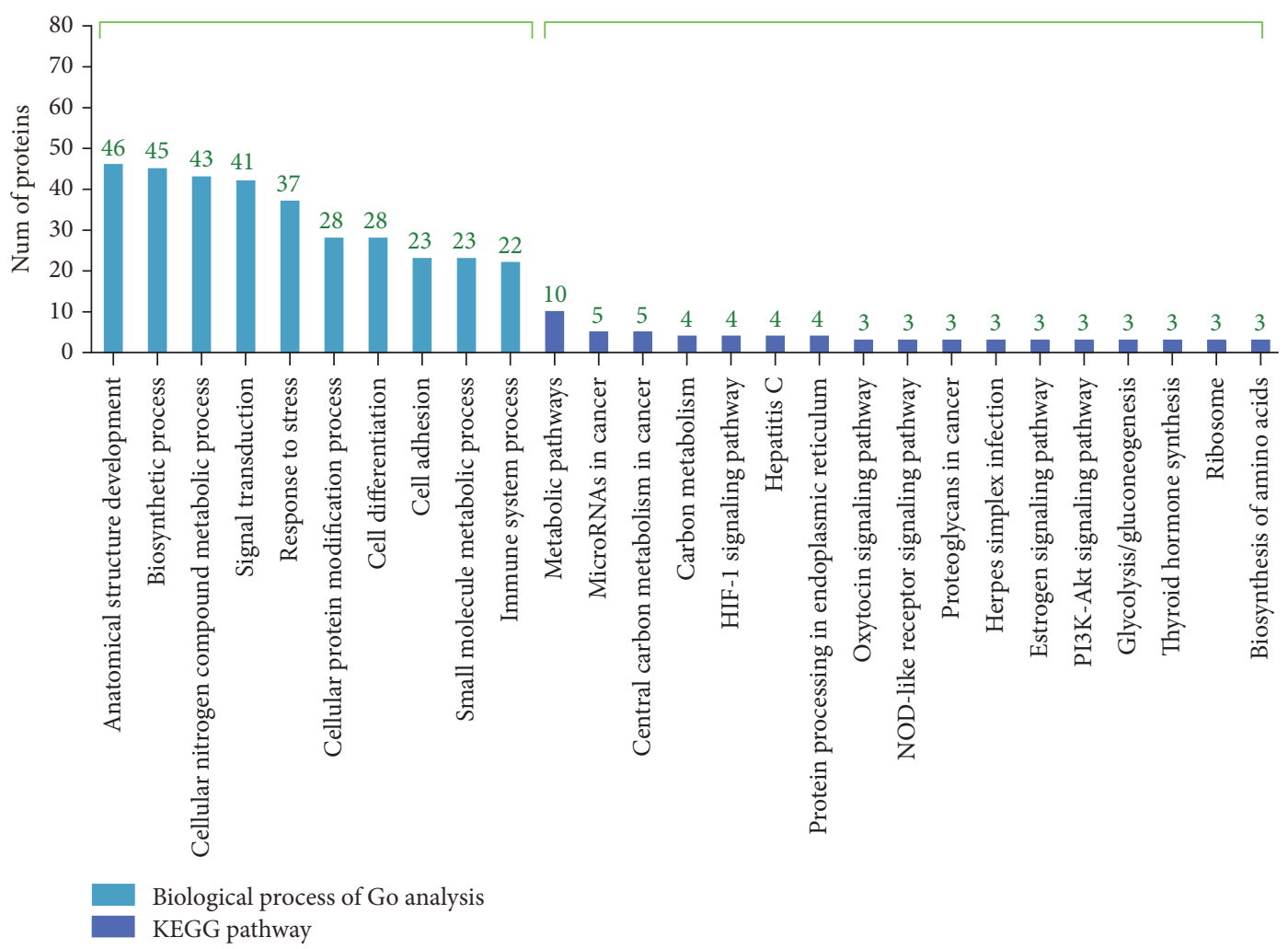

FIGURE 3: The functional classification of differentially expressed proteins using Go analysis (biological process) and KEGG Pathway. FDR adjusted $p$ value of 0.05 was considered statistically significant.

proteins may induce apoptosis of cancer cells by interfering with biosynthesis, response to stress, energy metabolism, and other signal transduction pathways.

Tumors develop resistance to targeted therapies through overexpression of multixenobiotic resistance proteins and rapid replication. Further, hyperproliferation, drug resistance, and metastasis are driven by multiple kinase cascades, and interruption of only one pathway may be insufficient for tumor control. Therefore, single drugs targeting multiple kinases or biological processes (e.g., DNA replication and growth factor transduction) may be required to fully inhibit the growth of cancer cells [11]. Indeed, recent studies have confirmed that the attrition rates of multitargeting agents are lower than single-targeting agents [12]. The initial design concept of JDF12 was to produce an agent with synergistic anticancer effects through inhibition of EGFR transduction and DNA alkylation, and these properties were reconfirmed in this study. We speculate that the EGFR-blocking property may inhibit the activation of DNA repair pathways by DNA alkylation, while DNA alkylation may reduce drug resistance caused by EGFR inhibition.

EGFR signaling pathways are strongly associated with cell survival. Increasing the expression levels of EGFR family proteins, including EGFR, ErbB2, ErbB3, and ErbB4, can promote the growth of cancer cells [13]. Overexpression of EGFR has also been linked to anticancer drug resistance and greater aggression of breast, lung, and other cancers [1416]. Multiple transduction cascades including the Ras/MAPK pathway are believed to mediate cell survival following EGFR activation [17]. Expression of EGFR was significantly lower in JDF12-treated PCa cells after $24 \mathrm{~h}$, while cells exposed to JDF12 for only $2 \mathrm{~h}$ did not show this response [8]. Further, no significant cell death was observed within $12 \mathrm{~h}$. This temporal association suggests that EGFR downregulation by JDF12 may be required to induce apoptosis, although the additional DNA-alkylating effect may also contribute.

The tumor suppressor TP53 is one of the most frequently downregulated proteins in cancers, and many p53 mutants are oncogenic [18]. TP53 contributes to multiple cellular processes associated with cell proliferation and survival, including metabolism, the DNA damage response, senescence, stemness, and differentiation. Among these processes, regulation of the DNA damage response may be the most relevant to cancer [19]. Activation of p53 is the key element in response to DNA damage. ATM (ataxia telangiectasia mutated) and ATR (ataxia telangiectasia- and Rad3-related) are activated by double- or single-strand breaks, which inhibits p53 degradation and leads to transcriptional activation and chromatin remodeling [20]. Moreover, p53 is linked to other proteins involved in apoptosis induction [21]. The expression of TP53 was upregulated by JDF12, suggesting that JDF12 may induce cancer cell apoptosis through TP53 signaling pathways. Indeed, overexpression of TP53 can inhibit the growth of tumors, and again suppression of ERGR signaling may further enhance this proapoptotic effect. Due to the reason that DU-145 cells have mutations in TP53 [22], qPCR was performed to confirm some important changes in other prostate cell lines, including PC3 and 22Rv1. Results suggested that 


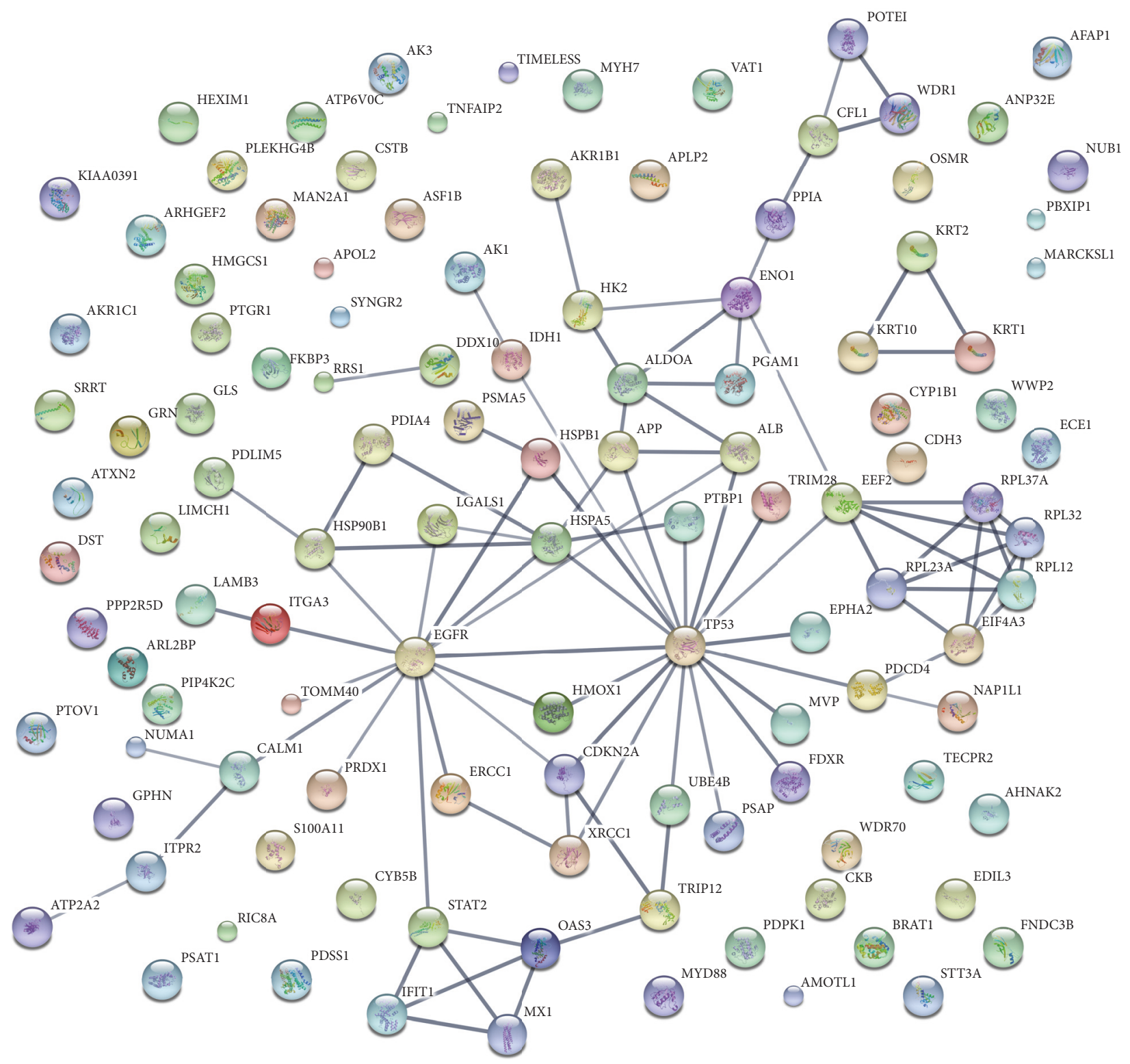

FIGURE 4: The interaction analysis of differentially expressed proteins using STRING analysis (confidence view). The PPI network score was set to the high level (0.700). Stronger associations are represented by thicker lines. EGFR, TP53, and HSPA5 were identified as "hubs."

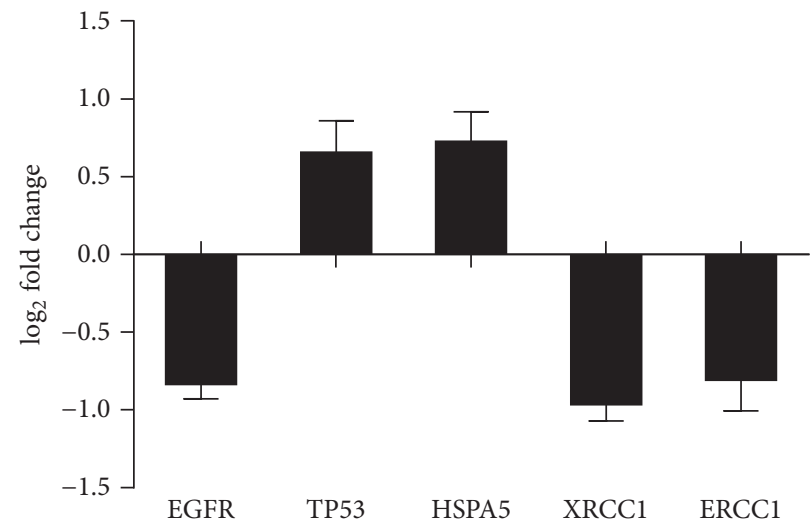

FIGURE 5: The expression level of some important proteins detected by iTRAQ. Qualification criteria for peptides were unused confidence score $\geq 1.3$ and confidence level $\geq 95 \%$. Average fold change $\geq 1.5$ was classified as upregulated and average fold change $\leq 0.67$ was defined as downregulated. 


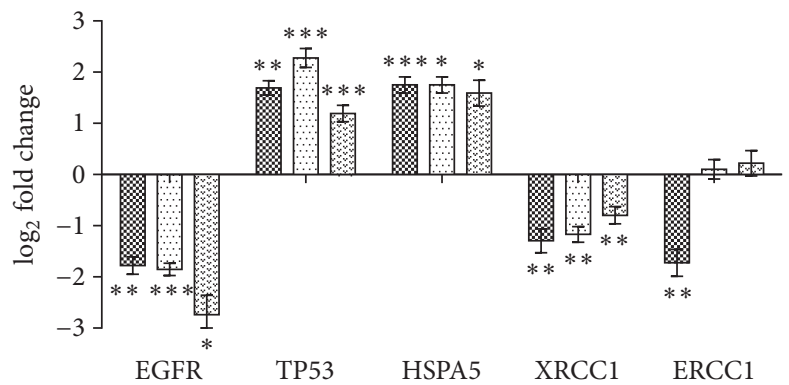

网 DU145

…… PC3

$22 \mathrm{Rv} 1$

FIGURE 6: The expression level of mRNA for some important proteins in DU145, PC3, and 22Rv1 cell lines. All samples were measured three times, and results are showed as mean \pm standard deviation. Statistical analysis was performed independently in each cell line. ${ }^{*} p<0.05$, ${ }^{* *} p<0.01$, and ${ }^{* * *} p<0.001$.

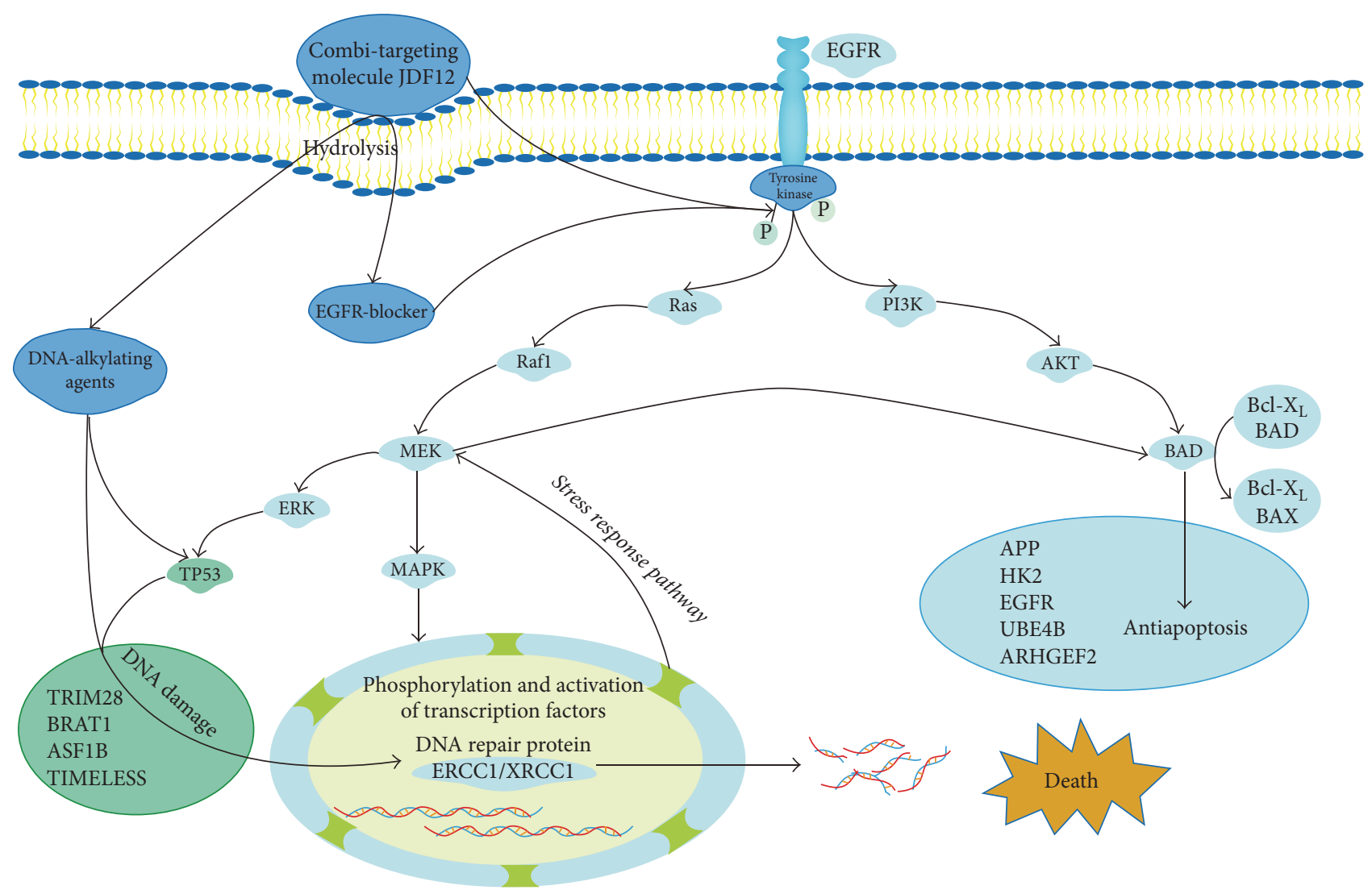

Downregulated

Upregulated

FIGURE 7: The proposed possible anticancer mechanisms and signaling pathways of JDF12-induced apoptosis in DU145 cells.

the anticancer effects of JDF12 are generalizable to multiple cell lines, while the detailed mechanisms may be different. Although these three cell lines are all prostate cells, they are at different stages of prostate cancer, and isolated from different tissues, which may contribute to the difference in mRNA expression of ERCC1 among DU145, 22Rv1, and PC3.
HSPA5 is also overexpressed in some cancers, including breast, hepatocellular, and lung cancer [23-25]. Upregulation of HSPA5 promotes drug resistance as well as metastasis, resulting in poor prognosis [26]. It was thus surprising to find that JDF12 induced HSPA5 overexpression, in contrast to many other anticancer drugs. However, the signaling 
pathways controlling tumor growth are driven by multiple kinases. HSPA5 is also strongly connected to autophagy, although this was not a planned target of JDF12. Upregulation of HSPA5 may be a compensatory response to JDF12. Nonetheless, such a response was insufficient to rescue PCa cells from the DNA-alkylating and EGFR-blocking effects.

Expression levels of ERCC1 and XRCC1, which play important roles in DNA damage repair pathways, were also downregulated by JDF12. Our previous study in nude mice revealed that JDF12 induced DNA damage by inhibiting ERCC1 and XRCC1 expression [9], consistent with the current findings. At the same time, inhibiting the EGFR signaling pathway may contribute to downregulated expression of ERCC1 and XRCC1, thereby augmenting the anticancer effects.

Although the anticancer effects of JDF12 are strong and superior to its prodrugs, the $\mathrm{IC}_{50}$ for JDF12 $(8.42 \mathrm{uM})$ is fairly high for an anticancer compound. Some useful compounds have $\mathrm{IC}_{50}$ 's in the $\mathrm{nM}$ range [27]. Differences in kind of drugs, cells, and time of treatment may take main responsibilities for it, but the experimental environment and operator may also have some contributions. All in all, JDF12 could potentially be an effective therapy for prostate cancer.

Combi-targeting drugs are promising anticancer agents, but the therapeutic mechanisms are more complex than those of single-targeting drugs. Indeed, our proteomics analysis revealed that EGFR, TP53, ERCC1, and XRCC1 constitute only a small fraction of the proteins regulated by JDF12 (although KEGG and STRING analyses identified these proteins as critical hubs in the interaction network). Further studies are needed to investigate the effects of the other proteins regulated by JDF12. Moreover, additional studies are needed to assess the anticancer mechanisms of JDF12 in animal models and the anticancer efficacy in patients.

\section{Conclusions}

EGFR and TP53 are critical signaling pathways underlying the anticancer efficacy of JDF12, but additional studies are required to confirm this link as well as to analyze the contributions of other JDF12-regulated proteins and signaling pathways. Nonetheless, this study is the first to assess the anticancer mechanisms of a combi-targeting drug at the cellular and molecular levels, thereby providing a foundation for further development of combi-targeting drugs as cancer therapies. Many current anti-mCRPC drugs inhibit androgen or androgen receptors [28]. Drugs with additional targets, notably EGFR signaling and the DNA damage response, could usher in a new era of anti-mCRPC treatment.

\section{Conflicts of Interest}

The authors declare that they have no conflicts of interest.

\section{Authors' Contributions}

Haofeng Zheng and Guancan Liang contributed to this paper equally.

\section{Acknowledgments}

This work was supported by the Science and Technology Planning Project of Guangzhou (Grant no. 201704020052); the Science and Technology Project of Guangdong (Grant no. 2013B021800084); the Fundamental Research Funds for the Central Universities (Grant no. 14YKPY25); and the Guangdong Natural Science Foundation (Grant no. 2014A030313131).

\section{References}

[1] G. Attard, C. Parker, R. A. Eeles et al., "Prostate cancer," The Lancet, vol. 387, no. 10013, pp. 70-82, 2016.

[2] R. L. Siegel, K. D. Miller, and A. Jemal, “Cancer statistics, 2017," CA: A Cancer Journal for Clinicians, vol. 67, no. 1, pp. 7-30, 2017.

[3] W. T. Lowrance, B. J. Roth, E. Kirkby, M. H. Murad, and M. S. Cookson, "Castration-resistant prostate cancer: AUA Guideline Amendment 2015," Journal of Urology, vol. 195, no. 5, pp. 14441452, 2016.

[4] F. Li and R. I. Mahato, "MicroRNAs and drug resistance in prostate cancers," Molecular Pharmaceutics, vol. 11, no. 8, pp. 2539-2552, 2014.

[5] D. Cohen, I. Kuperstein, E. Barillot, A. Zinovyev, and L. Calzone, "From a biological hypothesis to the construction of a mathematical model," Methods in Molecular Biology, vol. 1021, pp. 107-125, 2013.

[6] J. Meng, F. Guo, H. Xu, W. Liang, C. Wang, and X.-D. Yang, "Combination therapy using co-encapsulated resveratrol and paclitaxel in liposomes for drug resistance reversal in breast cancer cells in vivo," Scientific Reports, vol. 6, Article ID 22390, 2016.

[7] R. Benedetti, M. Conte, C. Iside, and L. Altucci, "Epigeneticbased therapy: From single- to multi-target approaches," International Journal of Biochemistry and Cell Biology, vol. 69, pp. 121-131, 2015.

[8] Y. Fang, Q. Qiu, J. Domarkas et al., "'Combi-targeting' mitozolomide: conferring novel signaling inhibitory properties to an abandoned DNA alkylating agent in the treatment of advanced prostate cancer," Prostate, vol. 72, no. 12, pp. 1273-1285, 2012.

[9] Y. Fang, J. Wu, T. Li et al., "Biological effects of novel combitargeting molecule and its effect on DNA repair pathway in hormone-refractory prostate cancer," American Journal of Cancer Research, vol. 5, no. 8, pp. 2387-2395, 2015.

[10] Y. Q. Fang, J. Y. Wu, T. C. Li et al., "Nanoparticle mediated chemotherapy of hormone refractory prostate cancer with a novel combi-molecule," American Journal of Translational Research, vol. 7, no. 8, pp. 1440-1449, 2015.

[11] S. Rao, A.-L. Larroque-Lombard, L. Peyrard et al., "Target modulation by a kinase inhibitor engineered to induce a tandem blockade of the epidermal growth factor receptor (EGFR) and c-Src: The concept of type III combi-targeting," PLOS ONE, vol. 10, no. 2, Article ID e0117215, 2015.

[12] I. Walker and H. Newell, "Do molecularly targeted agents in oncology have reduced attrition rates?" Nature Reviews Drug Discovery, vol. 8, no. 1, pp. 15-16, 2009.

[13] E. Henson, Y. Chen, and S. Gibson, "EGFR family members' regulation of autophagy is at a crossroads of cell survival and death in cancer," Cancers, vol. 9, no. 4, article 27, 2017.

[14] M. Juchum, M. Günther, and S. A. Laufer, "Fighting cancer drug resistance: Opportunities and challenges for mutation-specific 
EGFR inhibitors," Drug Resistance Updates, vol. 20, pp. 12-28, 2015.

[15] J. P. De Andrade, J. M. Park, V. W. Gu et al., "EGFR is regulated by TFAP2C in luminal breast cancer and is a target for vandetanib," Molecular Cancer Therapeutics, vol. 15, no. 3, pp. 503-511, 2016.

[16] Q. Wen, W. Wang, S. Chu et al., "Flot-2 expression correlates with EGFR levels and poor prognosis in surgically resected nonsmall cell lung cancer," PLoS ONE, vol. 10, no. 7, Article ID e0132190, 2015.

[17] W. Sangrar, C. Shi, G. Mullins, D. LeBrun, B. Ingalls, and P. A. Greer, "Amplified Ras-MAPK signal states correlate with accelerated EGFR internalization, cytostasis and delayed HER2 tumor onset in Fer-deficient model systems," Oncogene, vol. 34, no. 31, pp. 4109-4117, 2015.

[18] T. Soussi and K. G. Wiman, "TP53: An oncogene in disguise," Cell Death and Differentiation, vol. 22, no. 8, pp. 1239-1249, 2015.

[19] D. W. Meek, "Regulation of the p53 response and its relationship to cancer," Biochemical Journal, vol. 469, no. 3, pp. 325-346, 2015.

[20] G. Manic, F. Obrist, A. Sistigu, and I. Vitale, "Trial Watch: Targeting ATM-CHK2 and ATR-CHK1 pathways for anticancer therapy," Molecular \& Cellular Oncology, vol. 2, no. 4, p. e1012976, 2015.

[21] E. Wawryk-Gawda, P. Chylińska-Wrzos, M. Lis-Sochocka et al., "P53 protein in proliferation, repair and apoptosis of cells," Protoplasma, vol. 251, no. 3, pp. 525-533, 2014.

[22] A. van Bokhoven, M. Varella-Garcia, C. Korch et al., "Molecular characterization of human prostate carcinoma cell lines," Prostate, vol. 57, no. 3, pp. 205-225, 2003.

[23] Y.-W. Chang, H.-A. Chen, C.-F. Tseng et al., "De-acetylation and degradation of HSPA5 is critical for E1A metastasis suppression in breast cancer cells," Oncotarget, vol. 5, no. 21, pp. 10558-10570, 2014.

[24] Z. Yang, L. Zhuang, P. Szatmary et al., "Upregulation of heat shock proteins (HSPA12A, HSP90B1, HSPA4, HSPA5 and HSPA6) in tumour tissues is associated with poor outcomes from HBV-related early-stage hepatocellular carcinoma," International Journal of Medical Sciences, vol. 12, no. 3, pp. 256-263, 2015.

[25] X. Zhao, X. Liu, and L. Su, "Parthenolide induces apoptosis via TNFRSF10B and PMAIP1 pathways in human lung cancer cells," Journal of Experimental and Clinical Cancer Research, vol. 33, no. 1, 3 pages, 2014.

[26] H.-A. Chen, Y.-W. Chang, C.-F. Tseng et al., "E1A-mediated inhibition of HSPA5 suppresses cell migration and invasion in triple-negative breast cancer," Annals of Surgical Oncology, vol. 22, no. 3, pp. 889-898, 2015.

[27] Y. Shen, L. Zeng, R. Novosyadlyy et al., "A bi-functional antibody-receptor domain fusion protein simultaneously targeting IGF-IR and VEGF for degradation," $m A b s$, vol. 7, no. 5, pp. 931945, 2015.

[28] L. B. Valenca, C. J. Sweeney, and M. M. Pomerantz, "Sequencing current therapies in the treatment of metastatic prostate cancer," Cancer Treatment Reviews, vol. 41, no. 4, pp. 332-340, 2015. 

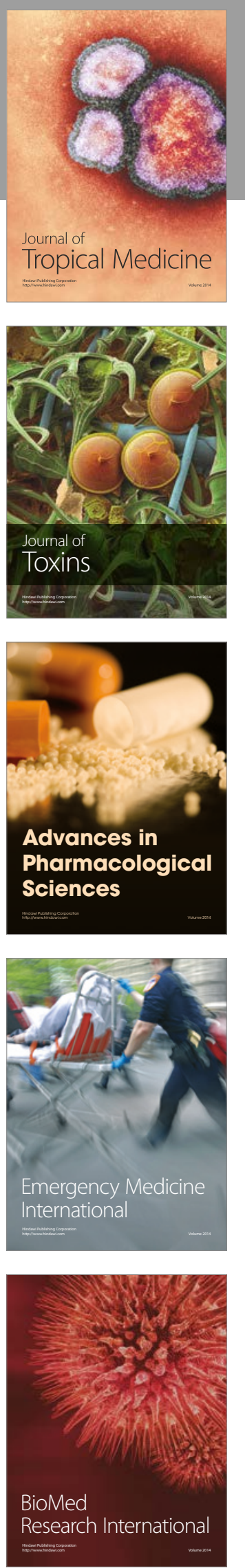
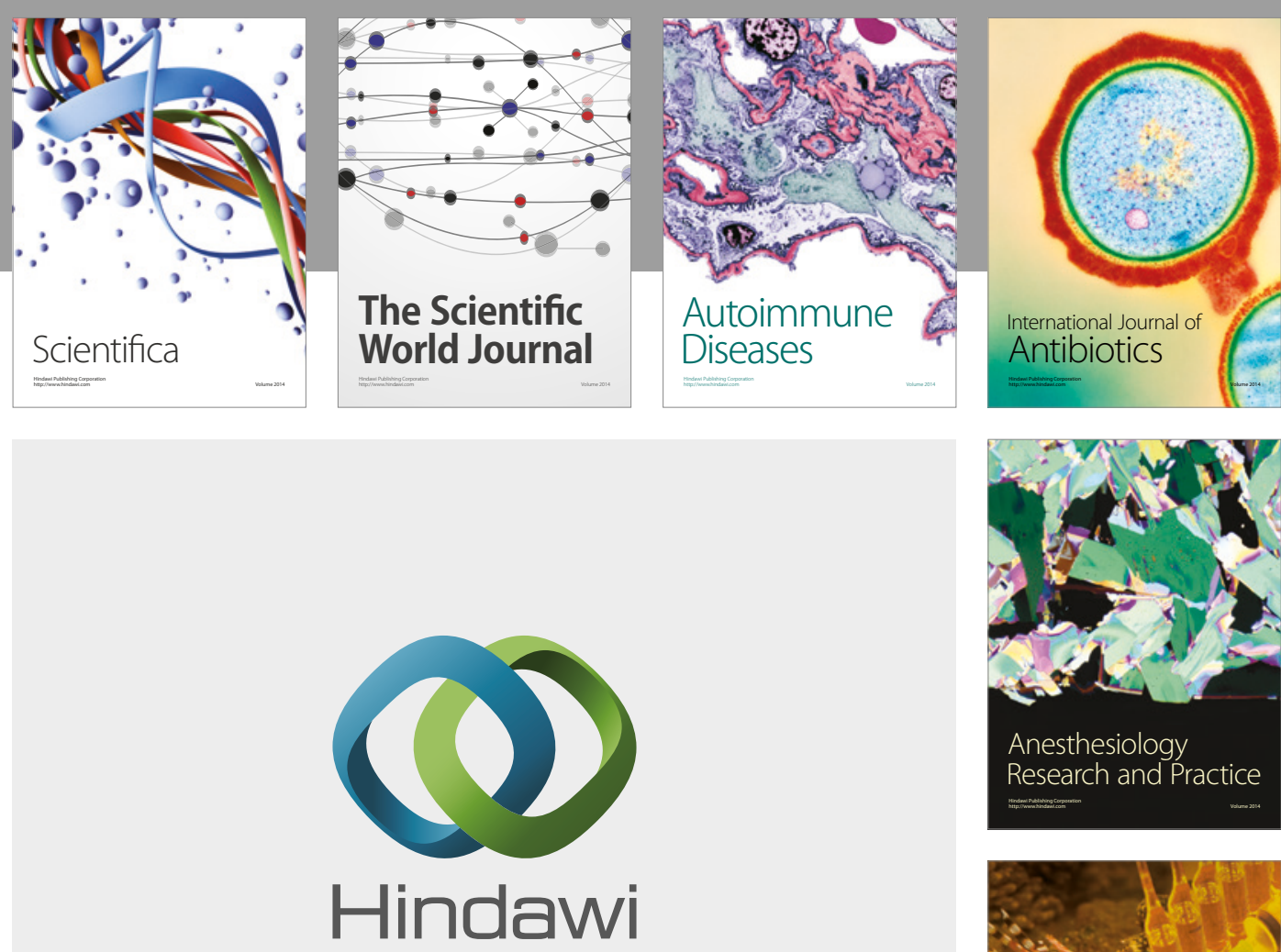

Submit your manuscripts at

https://www.hindawi.com
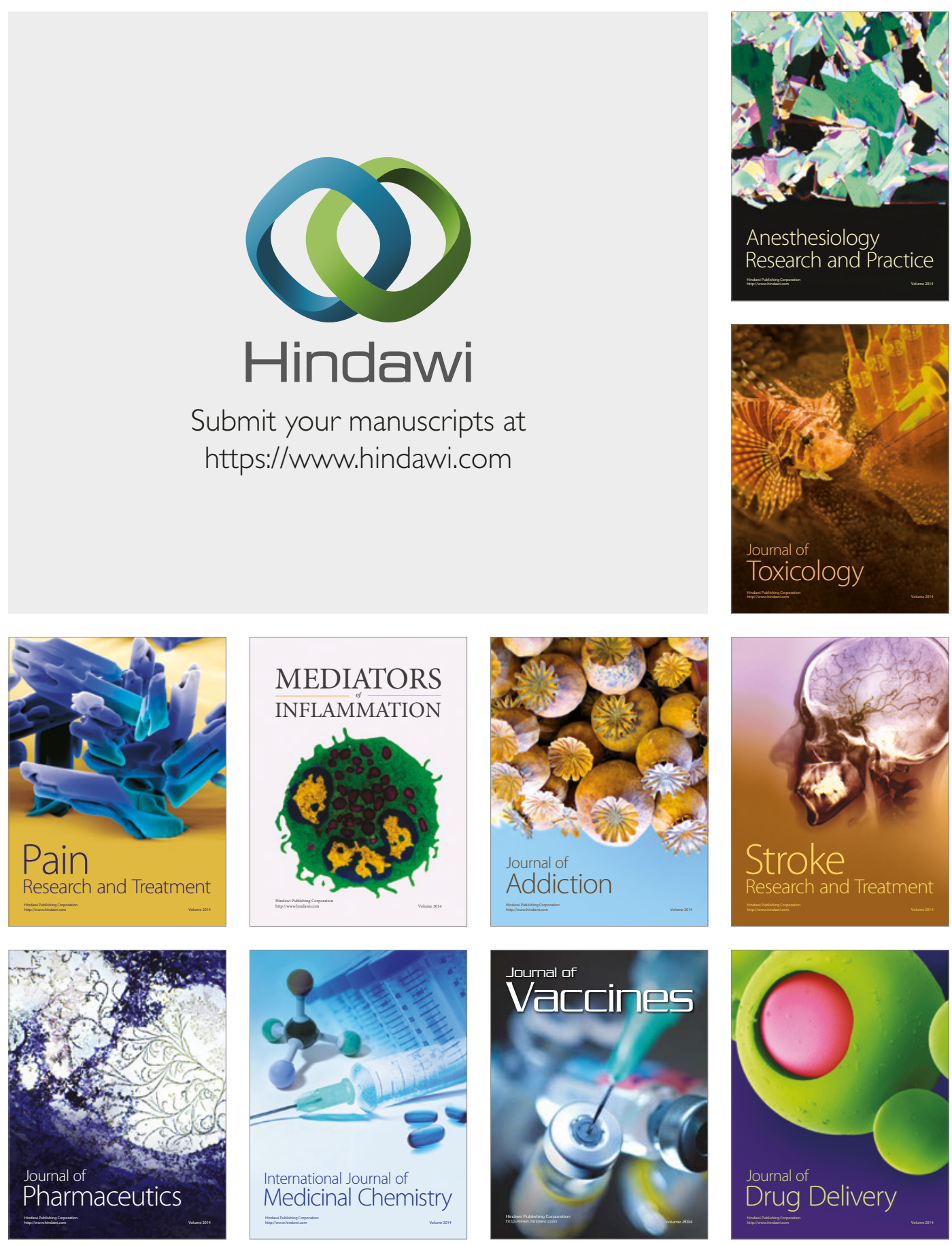